VERTAISARVIOITU

KOLLEGIALT GRANSKAD

PEER-REVIEWED

www.tsv.fi/tunnus

\title{
UTTALET I LÄROBÖCKER I SVENSKA SOM ANDRASPRÅK FRÅN BEGRIPLIGHETSPERSPEKTIV
}

\author{
Henna Heinonen, Jyväskylän yliopisto
}

\begin{abstract}
I denna artikel studerar jag hur uttal presenteras i finska gymnasieläroböcker $(n=10)$ i svenska som andra språk. Syftet är att undersöka vilka uttalsdrag som tas upp i läroböckerna och relationen mellan dessa drag och begriplighet. Metoden som jag använder är kvalitativ innehållsanalys.
\end{abstract}

Prosodiska drag har ansetts ha en stor betydelse för begriplighet. Vad det gäller svenska är speciellt satsrytm viktig. Analysen visar dock att uppmärksamheten oftast fästs vid enskilda segment (språkljud) och ord. Uttalet av hela satser övas också men regler eller anvisningar om produktionen av prosodiska drag presenteras bristfälligt. Att ange explicita råd och att göra inläraren medveten har i tidigare undersökningar noterats vara effektivt eller till och med nödvändigt för inlärning av prosodin.

Uttalsmålet för inlärarna på denna nivå är att uttalet är helt begripligt och att inläraren kan tillämpa flera uttalsregler. Att det saknas regler och anvisningar i läroböckerna medför att läraren har en stor roll i att inläraren når målen i uttalet. Presentationen och övandet av prosodiska drag bör vara i nyckelposition i undervisning som syftar till ett begripligt uttal.

Nyckelord: begriplighet, läroboksanalys, uttal

Skribentens kontaktuppgifter

Henna Heinonen

henna.m.heinonen@jyu.fi 


\section{INLEDNING}

Läroböcker spelar en markant roll i den finländska språkundervisningen. De styr oftast innehållet - det som saknas i läroböckerna saknas sannolikt också i undervisningen (Tergujeff, 2013) - och även kursmålen (Luukka m.fl., 2008). Ändå har läroböckerna analyserats mindre i språkvetenskapliga studier. I de gjorda analyserna har vissa aspekter ifrågasatts. Alanen (2000) upptäckte att språkbruket i finska gymnasieläroböcker i svenska inte alltid motsvarar språkbruket i verkligheten. Vaakanainen och Mäkilä (2018) gjorde likartade iakttagelser i läroböcker för högstadieundervisning och önskade att språkvetenskapliga analyser kunde utnyttjas mer vid utvecklingen av läromaterial. Salo (2006) ansåg att läroböckerna tycks ha ett normativt grepp och inte skilja mellan skriftligt och muntligt språkbruk. Detta medför att inläraren förblir omedveten om vilka sätt att uttrycka sig som är accepterade eller naturliga i olika kommunikationssammanhang (Salo, 2006).

Uttalets roll i finska läroböcker i svenska har analyserats för det mesta i kandidat- och magisteravhandlingar (se dock Tergujeff, 2013, om läroböcker i engelska). Resultaten visar att gymnasieläroböcker har varierande muntliga övningar men uttalet behandlas ensidigt som en företeelse som innefattar främst segment och enskilda ord (Salenius, 2011). I vissa läroböcker saknas explicita övningar i uttal helt (Kulmala, 2013). Det som presenteras mindre är uttalet av (sats)prosodiska drag (Salenius, 2011; Tergujeff, 2013) vilket från begriplighetsperspektivet har ansetts viktiga medan uttalet av segment förknippas oftast med graden av främmande accent (se kapitel 2). Undervisningen syftar dock primärt till ett lättbegripligt och kommunikativt välfungerande uttal (t.ex. Grunderna för gymnasiets läroplan, 2003; 2015; Levis, 2005), och för att inläraren ska kunna nå målet är det angeläget att de viktigaste prosodiska dragen i målspråket också ingår i (uttals)undervisningen och i läroböckerna.

I föreliggande undersökning studerar jag hur uttal och dess relation till begriplighet beaktas i tio finska gymnasieläroböcker för medellång lärokurs i svenska (målet nivå B1.1. i den europeiska referensramen). Syftet är att analysera vilka uttalsdrag presenteras i läroböckerna och sambandet mellan dragen och begripligheten. Därtill analyserar jag sättet att presentera uttalsdragen. Jag besvarar följande forskningsfrågor:

(i) Vilka uttalsdrag tas upp i läroböckerna?

(ii) Hur beaktas relationen mellan uttalsdrag och begriplighet?

(iii) På vilket sätt presenteras uttalsdragen?

Undersökningen är aktuell eftersom muntliga färdigheter planeras att bli en del av studentexamen i det andra inhemska språket och i främmande språk i Finland. Samtidigt finns det få tillämpade studier om uttalet i språkundervisningen. Studien ger en bild av uttalsdrag som presenteras i läroböckerna utgivna av två finländska bokförlag och dragens relation till inläraruttalets begriplighet. Genom analysen framgår eventuellt behov för tilläggsmaterial.

\section{BEGRIPILIGHETS-}

\section{PERSPEKTIVET I SVENSKT UTTAL OCH UTTALSUNDERVISNING}

Uttal som begrepp anses ibland omfatta endast enskilda segment (språkljud), och ord (en snäv uppfattning om uttalet, se Derwing m.f., 1998). De är en viktig del av uttalet men täcker inte hela begreppet. Vid sidan av segment omfattar uttal prosodiska drag såsom rytm, betoningar, intonation, taltempo och durationer. Prosodi i målspråket har kanhän- 
da inte varit så bekant för alla andraspråksinlärare och kanske inte heller för alla språklärare. En anledning till det kan vara att prosodin har presenterats mindre i finska läroböcker i främmande språk (se t.ex. Salenius, 2011, om läroböcker i engelska och svenska; Tergujeff, 2013, om läroböcker i engelska), som ändå är det primära undervisningsmaterialet.

Inom uttalsforskningen är det sedan tidigare känt att prosodiska drag är av stor betydelse för kommunikationen och begripligheten (t.ex. Bannert, 1984; Lynch, 1998; Saito, Trofimovich \& Isaacs, 2016; Thorén 2008). Om språkinläraren behärskar en målspråksliknande prosodi har lyssnaren lättare att begripa större enheter i talet, dvs. ord, fraser och satser. Avvikande prosodi kan leda till att lyssnaren inte känner igen ordet eller går miste om den viktigaste informationen i satsen (Abelin \& Thorén, 2015; Hahn, 2004). Avvikelser i segmentuttalet har inte ansetts lika betydelsefulla: Fast ett segment uttalas så pass avvikande att ordets betydelse förändras (t.ex. [mu:s] i stället för [mt:s]) avslöjar kontexten ofta den avsedda betydelsen (se t.ex. Lintunen, 2014). Ett avvikande uttal av segment är ändå lätt för en lyssnare att uppmärksamma och således har det oftast ansetts påverka graden av upplevd främmande accent och/ eller inföddlikhet och prosodiska drag till begripligheten (Kuronen \& Zetterholm, 2017; Lintunen, 2014; Saito m.fl., 2016).

Prosodi inkluderar flera olika drag och för att kunna bestämma vilka av dem som är betydelsefulla för kommunikationen behöver målspråket och källspråket granskas närmare: de avgörande dragen kan variera mellan språkparen (Crowther m.fl., 2015). Om begripligheten av finskspråkiga talarnas uttal av svenska har det gjorts få empiriska undersökningar, men de har visat att speciellt satsrytmen är viktig (Bannert, 1984; Heinonen, 2018). Med avseende på rytmen skiljer finska och svenska från varandra. Svenskans rytm karakteriseras av att den satsbetonade delen (stavelsen) framhävs ur de obetonade delarna främst genom längre duration men också genom förändringar i intonationen och intensiteten (Fant \& Kruckenberg, 1994). Genom förändringarna i dessa korrelat har den svenskspråkiga lyssnaren lätt att förankra med det mest informativa i satsen. Finskans rytm har beskrivits som mer stavelsebaserad, dvs. de betonade och obetonade stavelserna avviker inte stort från varandra fonetiskt (se t.ex. Kjellin, 2002; Vihanta, 1990). Den rytmiska skillnaden mellan språken kan påverka lyssnarperceptionen. Om den finska rytmen överförs till svenskt uttal kan det leda till att för många eller för få delar i satsen upplevs som betonade. Detta kan låta annorlunda i svenska öron (Kuronen \& Tergujeff, 2017) och påverka också begripligheten av svenskt uttal: kontrasten mellan betonade och obetonade stavelser saknas i ett mindre begripligt uttal (Bannert, 1984; Heinonen, 2019). Det är dock viktigt att minnas att talarna kan ha olika språkliga bakgrunder och tidigare studier i andra språk vilka också kan avsätta spår i uttalet av målspråket. Således påverkas uttal av främmande språk inte endast av talares förstaspråk (se t.ex. Wrembel, 2010).

Uttalet av segment har naturligtvis en inverkan på lyssnarperceptionen. Antalet avvikelser kan vara avgörande men det verkar finnas vissa segment som är mer betydelsefulla än andra; vissa fonem kan anses ha en större funktionell vikt än andra (Munro \& Derwing, 2006). I till exempel finskspråkiga talares svenska verkar uttal av tje-ljudet och klusilerna vara viktigare för begripligheten (Bannert, 1984; Heinonen, 2018). Enligt Heinonens (2018) analys präglas ett mindre begripligt uttal av svenska av att tonande och tonlösa klusiler inte avviker från varandra. Också en avvikande realisering av grafemet $<\mathrm{g}>$ (t.ex. 'gärna' [tsæ:rna], 'ryggen' [ryk:en]) och tje-lju$\operatorname{det}$ (realiseras som [k] eller [ts]) verkar leda 
till en lägre begriplighetsvärdering. Däremot tycks uttal av /u/, / $\mathrm{t} /$ och sje-ljudet inte vara så betydelsefullt: talaren upplevs som helt förstådd trots avvikande uttal av dessa segment $\mathrm{i}$ längre yttranden (Heinonen, 2018).

Vad det gäller uttal verkar den finländska undervisningen - såsom läroböckerna - i svenska fokusera mer på svåra ord och segment, speciellt på vokaler, och mindre på prosodiska drag (Huhtamäki \& Zetterholm, 2017). Detta fokus kan göra inlärningen av satsprosodin svårare. $\mathrm{Om}$ inläraren enbart koncentrerar sig på uttalet av enskilda segment och ord kan det i längre yttranden resultera i hackig rytm med lika långa stavelser, pauser eller för många intonationstoppar och således blir satsbetoning svårare att identifiera (Jones, 1997; Kautonen 2019; Kjellin, 2002; se även Lintunen, 2014). Detta kan göra talet svårbegripligt (Heinonen, 2019; se också Hahn, 2004).

Om inläraren inte får explicit undervisning i prosodiska drag beror inlärningen av dem mycket på den intuitiva förmågan hos inläraren att tillägna sig dem. Det har dock framgått att detta sätt är mindre effektivt vid uttalsinlärningen än ett explicit sätt, dvs. att man medvetandegör, visualiserar, ger uttalsregler, granskar mål- och källspråket kontrastivt och använder fonetiska tecken (Derwing m.fl., 1998; Lintunen, 2004; Ramírez Verdugo, 2006, mer om den analytisk-lingvistiska approachen se Celce-Murcia m.fl., 2010: 2). Explicit undervisning har ansetts vara nästintill nödvändig i t.ex. övningar i satsbetoning: de anses inte nyttiga utan förklaringar (Derwing, Diepenbroek \& Foote, 2013). Om inläraren förblir omedveten om målspråkets prosodi, är det sannolikt att hen tillämpar det prosodiska mönstret i sitt förstaspråk också i målspråket (se t.ex. Vihanta, 1990). Expliciteten, speciellt uttalsregler, nämns också i målbeskrivningar för nivå B1.1 i GLGY (2015: 251): "Den studerande - - kan tillämpa flera grundläggande uttalsregler också på andra än inövade uttryck.” Språklärare själva (också språkinlärare, se Tergujeff, 2013) betraktar uttalet som ett viktigt delområde och begripligheten som ett relevant inlärningsmål men de har dock sagt sig önska mer kunskap om uttalsundervisning (Huhtamäki \& Zetterholm, 2017; Tergujeff, 2013). På grundval av skillnaderna mellan teori (dvs., de prosodiska dragens betydelse för kommunikationen) och praktik (dvs., knappheten av prosodiska drag i undervisningen) kan det försiktigt spekuleras hur pass medvetna språklärare och andra aktörer inom språkundervisningen är om de begriplighetsrelaterade uttalsdragen.

\section{MATERIAL OCH METODER}

I denna artikel rapporterar jag en kvalitativ innehållsanalys av 10 finska gymnasieläroböcker för medellång lärokurs i svenska ${ }^{1}$. Före analysen gjorde jag en systematisk kategorisering. Läroböckerna i analysen har givits ut av två stora bokförlag: Otava och Sanoma Pro. Läroboksserierna heter Fokus (Otava) och Precis (Sanoma Pro). I analysen ingår fem läroböcker av respektive bokförlag. Till serierna och specifika läroböcker hänvisar jag i fortsättningen bara med seriens namn och kursnummer. Böckerna är avsedda för de obligatoriska kurserna RUB1-5 (årskurs 1-3 i gymnasium) och följer grunderna för gymnasiets läroplan 2015 (GLGY, 2015). Inlärarna på denna nivå har tidigare studier i svenska i 3 år och de syftar till att nå nivån B1.1 i den europeiska referensramen. De analyserade läroböckerna är av olika typer: Fokus består av tryckta böcker medan Precis består av parallella digitala upplagor.

\footnotetext{
1 Svenska är ett obligatoriskt ämne för finskspråkiga och man får välja lång eller medellång lärokurs $\mathrm{i}$ svenska. Om man börjar studierna i årskurs 2 (som 8-åring) är lärokursen lång A1. Det är vanligare att man börjar studera svenska senare, i årskurs 6 (som 12-åring), och då är lärokursen medellång (YTL, 2016). I gymnasiet studerar man 5 obligatoriska och 2 valfria kurser i medellång lärokurs (GLGY, 2015).
} 
Analysen omfattar endast läroböckerna. Annat material såsom lärarmaterial och eventuellt tilläggsmaterial på internet har jag utelämnat ur analysen. Genom att avgränsa analysen till läroböckerna utformar analysen en helhet som jag önskar spegla inlärarperspektivet: det som inläraren har till hands står i centrum för intresset i denna undersökning. Annat material kan däremot vara ett intressant ämne för fortsatta undersökningar.

För analysen gick jag igenom övningarna i läroböckerna systematiskt. Jag kategoriserade dem enligt färdigheten de bidrar till (läsförståelse, skrift, grammatik, hörförståelse, muntlig färdighet och uttal) och avgränsade analysen till uttalsövningarna och andra hänvisningar till uttalet. Som uttalsövningar klassificerade jag övningar som har något av följande drag: (i) ett eller flera specifika uttalsdrag presenteras som ett tydligt inlärningsmål, (ii) speciell koncentration på uttalet krävs av inläraren och/eller (iii) uttalsanvisningar eller uttalsregler presenteras i samband med övningen. Andra typer av muntliga övningar var mångtaliga i båda serierna och de kan tänkas bekräfta och träna de redan inlärda uttalsdragen samt utveckla motoriken och automatiseringen av uttalet. Fokus i generella muntliga övningar var dock inte på uttalsinlärningen, och därför har de bortsetts från. Förutom uttalsövningarna valde jag också andra hänvisningar till uttalet såsom tipsrutor, regler och förord till analysen. Jag har inte bedömt riktigheten eller exaktheten hos uttalsreglerna.

Uttalsövningarna och hänvisningarna till uttalet kategoriserade jag vidare på segment-, ord- och satsnivå. Med segmentnivån syftar jag till vokal- och konsonantuttal. Segmentnivån omfattar både korta och långa fonem med avseende på kvaliteten: om koncentrationen inte fästs vid kontrasten mellan korta och långa ljud eller betoning har jag ansett att fokus riktas till kvaliteten. Ordnivån innebär i sin tur kvantitet och ordbetoning. Kate- goriseringen var inte entydig då syftet med framhävningarna (fet stil eller understrykning) inte framkom i övningen. Den feta stilen kunde tolkas hänvisa till kvaliteten och understrykningen till ordbetoningen (jfr' 'en nationaldag', Fokus 2, s. 17). Därför har till exempel fonemet /a/ i 'dator' (Fokus 1, s. 47) och 'författare' (Fokus 3, s. 37) kategoriserats i både segmentnivån och ordnivån då det var både skrivet med fet stil och understruket. Satsnivain innebär fraser och hela meningar.

Utöver analys av uttalsdragen studerar jag hur resultaten relaterar till tidigare undersökningar om (finskspråkiga talares) uttal av svenska och begriplighet. I analysen koncentrerar jag mig också på approachvalet i övningarna: om de är explicita eller implicita.

\section{ANALYS}

I detta kapitel analyserar jag uttalsövningar och andra hänvisningar till uttalet i 10 gymnasieläroböcker i svenska. Uttalsdrag som tas upp i läroböckerna behandlar jag i avsnitt 4.1. Tabell 1 sammanfattar dessa uttalsdrag samt uttalsdrag som har upptäckts svåra för finskspråkiga talare (Bannert, 1984; Kautonen m.fl., 2016; Kuronen, 2016). Uttalsdragen analyserar jag från begriplighetsperspektivet i avsnitt 4.2. Sättet att presentera uttalet behandlar jag i avsnitt 4.3. I avsnitt 4.4. tar jag upp andra anmärkningar om begriplighet och uttalets roll i läroböckerna. Exempel på uttalsövningar i Precis anges i form av bilder medan exempel på uttalsanvisningar i Fokus anges som direkta citat i Exempel 1 och 2 av upphovsrättsliga skäl. 
Tabell 1. Uttalsdrag i Fokus och Precis och uttalsdrag som visat sig vara svåra för finskspråkiga talare (Bannert, 1984; Kautonen m.fl., 2016; Kuronen, 2016). Segmenten under läroboksserierna är listade i frekvensordning.

\begin{tabular}{|c|c|c|c|c|}
\hline \multicolumn{2}{|c|}{ Uttalsdrag } & \multirow{2}{*}{$\begin{array}{l}\text { Fokus } \\
\begin{array}{l}\text { [u:], [æ], [u], [u:], [æ:], } \\
{[\mathrm{u}],[\mathrm{o}],[\mathrm{\varepsilon :}],[\mathrm{o}:],[\mathrm{i}:],} \\
{[\mathrm{e}:],[\mathrm{a}:],[\mathrm{a}]}\end{array}\end{array}$} & \multirow{2}{*}{$\begin{array}{l}\text { Precis } \\
\text { [u:], [o], [æ], [u], [e:], } \\
{[o:],[œ:],[\mathrm{u}],[\varepsilon],[\mathrm{a}:],} \\
{[\varnothing:],[\mathrm{u}],[æ:],[\mathrm{e}],[\varepsilon:],} \\
{[\mathrm{i}:],[\mathrm{y}:]}\end{array}$} & \multirow{2}{*}{$\begin{array}{l}\text { Svåra för finsksprå- } \\
\text { kiga talare } \\
\text { [a:], [e:], [o:], [u:], } \\
\text { [y:] }\end{array}$} \\
\hline $\begin{array}{l}\text { Segment- } \\
\text { nivå }\end{array}$ & Vokaler & & & \\
\hline & $\begin{array}{l}\text { Konso- } \\
\text { nanter }\end{array}$ & $\begin{array}{l}\text { sje-ljud, [j], tje-ljud, } \\
{[\mathrm{g}],[\mathrm{k}],[\eta],[\eta(n)]}\end{array}$ & $\begin{array}{l}\text { sje-ljud, tje-ljud, [k], } \\
{[\mathrm{j}],[\mathrm{g}],[\mathrm{\eta}],[\mathrm{\eta}(\mathrm{n})],[\mathrm{s}],} \\
{[\mathrm{b}],[\mathrm{d}],[\mathrm{t}],[\mathrm{l}],[\mathrm{n}]} \\
{[\mathrm{p}],[\mathrm{d}]}\end{array}$ & $\begin{array}{l}{[\mathrm{b}],[\mathrm{p}],[\mathrm{g}],[\mathrm{k}],[\mathrm{d}],} \\
{[\mathrm{t}], \text { sje-ljud, tje-ljud }}\end{array}$ \\
\hline & Annat & $\begin{array}{l}\text { • ljudbortfall, t.ex. } \\
\text { 'värld' } \\
\text { • exceptionella uttal, } \\
\text { t.ex. 'service' }\end{array}$ & $\begin{array}{l}\text { •ljudbortfall, t.ex. } \\
\text { 'världen' } \\
\text { • exceptionella uttal, } \\
\text { t.ex. 'aktie' }\end{array}$ & - konsonantkluster \\
\hline \multirow[t]{2}{*}{ Ordnivå } & Kvantitet & $\begin{array}{l}\text { - regel } \\
\text { - minimala par }\end{array}$ & & \\
\hline & $\begin{array}{l}\text { Ord- } \\
\text { betoning }\end{array}$ & $\begin{array}{l}\text { - ordbetonings- } \\
\text { övningar } \\
\text { - ordbetoningens } \\
\text { placering }\end{array}$ & $\begin{array}{l}\text { - ordbetonings- } \\
\text { övningar } \\
\text { - ordbetoningens } \\
\text { placering } \\
\text { - ord på -or } \\
\text { - förkortningar } \\
\text { - sammansättningar } \\
\text { - prefixen 'be' och } \\
\text { 'för' }\end{array}$ & $\begin{array}{l}\text { - melodiförändring } \\
\text { i huvudbetonad } \\
\text { stavelse }\end{array}$ \\
\hline Satsnivå & $\begin{array}{l}\text { Sats- } \\
\text { betoning }\end{array}$ & $\begin{array}{l}\text { - frasövningar } \\
\text { (segment med fet } \\
\text { stil) } \\
\text { - satsövningar }\end{array}$ & $\begin{array}{l}\text { - rytm } \\
\text { - satsövningar } \\
\text { - vilka ordklasser } \\
\text { som oftast betonas }\end{array}$ & $\begin{array}{l}\text { - betoningens } \\
\text { fördelning inom } \\
\text { satsen / frasen }\end{array}$ \\
\hline
\end{tabular}

\subsection{Uttalsdragen i läroböckerna}

\subsubsection{Segmentnivå}

Vilka segment som presenteras i läroböckerna varierar mellan serierna (Tabell 1). I Fokus fokuseras på 20 olika segment under de fem obligatoriska kursernas gång. Störst uppmärksamhet får fonemet / $\mathrm{u}$ / vars upprepningsfrekvens är hög. Antal olika segment i Precis är större, 32 segment, och upprepningsfrekven- sen är jämn. Precis presenterar även nyanser såsom supradentaler (Precis 3, s.14) och den halvöppna allofonen [œ] av fonemet /ö/ (Precis 5, s. 14). För begripligheten är dessa inte relevanta men t.ex. [œ]-ljudet presenteras först i boken för den sista obligatoriska kursen, då denna typ av nyanser kan vara intressanta och motiverande att lära sig. I båda läroboksserierna förekommer också vissa exceptionella uttal och några ljudbortfall (Tabell 1). 
Konsonantkluster, vilka enligt Bannert (1984) har visat sig svåra för finskspråkiga, beaktas inte alls i läroböckerna. Det har dock inte rapporterats om svårigheter i konsonantkluster hos finskspråkiga talare i senare uttalsundersökningar (Heinonen, 2018; Kautonen 2019).

\subsubsection{Ordnivå}

Kvantitet och ordbetoning i svenska är betydelseskiljande (t.ex. 'gratis' / 'grattis', 'banan'/ 'banan'). Kvantiteten har en betydelseskiljande funktion också i finska ('pula' (sv. 'brist')/ pulla (sv. 'bulle')), men kvantitetsregler skiljer sig mellan språken: svenska har komplementär längd vilket förenklat innebär att vokalen är lång om den följs av en kort konsonant och den är kort före en lång, vanligtvis en dubbeltecknad konsonant (mer om komplementär längd, se t.ex. Bruce, 2010). Finska har inte liknande system utan långa och korta ljud kan följa varandra. Fastän kvantiteten har en viktig roll i svenska behandlas den kort eller inte alls i läroböckerna. I Fokus 1 anges regeln i förordet, men därefter övas kvantiteten specifikt endast med några minimala par (t.ex. 'glas', 'glass') i en övning i kursbok 2 och kursbok 4. I Precis saknas anvisningar om kvantiteten och komplementära längden men uppmärksamhet fästs vid långa vokalljud i några övningar med fet stil.

I svenska är längd också det viktigaste korrelatet för betoningen: det betonade segmentet är tydligt längre än de obetonade. Betoningen spelar inte så stor roll för kvantiteten i finska och obetonade segment kan också vara långa. Vad det gäller ordbetoningen presenterar båda serierna endast dess placering vilket är viktigt eftersom språken skiljer sig också i detta avseende: ordbetoningen i svenska är inte fastställd på den första stavelsen som det är i finska. I förordet i Fokus 1 anges det att ordbetoningen vanligen ligger i den första stavelsen i svenska och att betonade stavelser har under- strukits i ordlistorna om betoningen ligger på en annan stavelse än på den första. Vid sidan av ordlistorna förekommer understrykningarna i vissa ord i största delen av uttalsövningarna i Fokus. Ordbetoningen har markerats i ordlistorna också i Precis men dock från och med kursbok 4. I Precis är presentationen av ordbetoningen mer splittrad. Precis ger en generell beskrivning om betoningens placering $\mathrm{i}$ samband med en övning i kursbok 1 (Bild 1) och senare gällande ord som slutar på -or (t.ex. 'dator', Precis 4, s. 19), ord som gäller studier (Precis 5, s. 56), förkortningar (Precis 5, s. 128) och ord med prefixen 'be' eller 'för' (Precis 5, s. 147). I en övning uppmanas inläraren att fästa uppmärksamhet vid ordbetoningar (Precis 5, s. 52). Uttalet av sammansättningar övas i Precis 5, men det framgår dock inte vilket uttalsdrag som inlärare ska fokusera på. Vid sidan av ordbetoningens plats framkommer inte skillnader i ordbetoningen mellan finska och svenska, ordbetoningens betydelse för begripligheten eller dess betydelseskiljande funktion i läroböckerna.

\subsubsection{Satsnivå}

Fokus har några uttalsövningar där korta fraser övas i stället för enskilda ord. Uppmärksamheten fästs i dessa vid uttalet av segment med fet stil, t.ex. 'lära sig att sepositivtpå livet' (Fokus 4, s.33),'le mot någon', (Fokus 4, s. 59), 'all arbetserfarenhet är guld värd' (Fokus 5, s. 53). Den typen av övningar kan tänkas utveckla rytmen genom att binda ihop separata ord. Det finns dock en risk för att inläraren fokuserar på uttalet av de framhävda segmenten och således betonar dem fast de är i en obetonad ställning. $\AA$ andra sidan är det nyttigt att beakta också uttalet av obetonade delar, men om syftet är detta borde det dock framgå tydligt i övningen. 
10 A Kuuntele ja toista sanat.

Ruotsissa paino on yleensä sanan ensimmäisellä tavulla.

1 dator

2 konstigt

Useissa lainasanoissa paino on sanan viimeisellä tavulla.

fsv.

3 telefon

4 dokument

5 reparatör

Prepositiot, kuten $i, p a ̊, a v$, ovat painollisia, jos ne muodostavat ilmauksen yhdessä verbin kanssa.

6 stänga av

7 sätta på

LYSSNA OCH UPPREPA.

B Kuuntele ja toista lauseet.

1 Min dator slutade fungera.

2 Jag spillde läsk över telefonen.

3 Mamma hämtade datorn hos reparatören.

4 Jag stängde av datorn och satte på den igen

Bild 1. Ordbetoningsövning i Precis 1, s. 173. (sv. 'Lyssna och upprepa orden. Ordbetoningen i svenska är vanligen på första stavelsen. . I I de flesta lånorden är betoningen på sista stavelsen $\mathrm{i}$ ordet. . Prepositioner. na som i, på och av är betonade om de bildar ett uttryck med verbet. - Lyssna och upprepa meningarna.') ${ }^{2}$

Annars liknar läroboksserierna varandra på satsnivån. Båda serierna har uttalsövningar med fraser och hela meningar som inläraren uppmanas att lyssna på och upprepa. Satsövningarna står alltid efter uttalsövningar med ordlista med framhävda segment. Precis har en satsövning efter varje ordlista, men motsvarande satsövningar förekommer mer oregelbundet i Fokus. Det som präglar innehållet av satsövningar är att vissa av orden som förekommer i ordlistan i den föregående övningen förekommer också i satsövningen (Bild 1, Exempel 1). Fördelen är att användningen av de nya orden övas i en kontext direkt efter att inläraren har bekantat sig med uttalet. Tillägnandet av satsprosodin (rytm och intonation) kan dock få mindre uppmärksamhet om inläraren fokuserar mer på uttalet av det nya segmentet respektive orden i meningen (jfr Derwing m.fl., 1998; Jones, 1997).
$<$ Exempel 1 >

"c Tutustu tekstin 5 sanoibin. Kuuntele, toista ja lue ne ä̈neen parisi kanssa.

bo / asua, hos / luona, däremot / sitä vastoin, lugn och ro / rauha, forsterhem / sijaiskoti, tog /otti - -

d Kunnteleja toista lauseet. Lue ne sitten parisi kanssä̈äneen. 1. Mina föräldrar skiljdesfor länge sedan. 2. Efter skilsmässan boddejag hos min pappa 3. Min mamma träffade jag däremot sällan. 4. Det tog inte länge förrän mina syskon hamnadepå fosterhem." (Fokus 1, s. 91)

(sv. c Bekanta dig med ord i text 5. Lyssna, upprepa och läs dem högt med ditt par. - - d Lyssna och upprepa meningarna. Läs dem sedan högt med ditt par. --)

\footnotetext{
${ }^{2}$ Anvisningarna, uppmaningarna, tipsen och reglernai läroböckerna var endast på finska. Jag har översatt dessa till svenska $i$ analysdelen.
} 
En övning i Precis 4 behandlar satsbetoningen lite närmare. Övningen har satser med vissa framhävda ord och en lista över ordklasser som oftast blir betonade i en sats (Bild 2). Övningen är den enda som fäster inlärarens uppmärksamhet vid satsbetoningen. Denna övning har dock några svagheter. Vid sidan av de framhävda orden har satserna också andra ord som kan betonas eller är naturligare att betona (t.ex. Bild 2, 13B, mening 2). Därtill är listan över ordklasserna relativt lång: den har med nästan alla ordklasser. Övningen kan alltså anses som diffus - det kan bli oklart för inläraren var satsbetoningen ligger och vad den verkligen betyder.

Några meningar i satsövningarna kan karakteriseras som långa och med tanke på inlärningen av satsprosodin relativt svåra, t.ex. 'Engagemanget gav 50000 kronor som skick- ades till Rumänien via en hjälporganisation' (Precis 4, s. 128), 'Ungföretagare har många slags företagsidéer från skönhetsprodukter till städtjänster' (Precis 5, s. 115) (se även Exempel 1, övning d, mening 4.; Bild 2, 13B, mening 2.). Långa och komplicerade meningar kan göra det svårt att tillägna sig satsprosodiska uttalsdrag, speciellt om inläraren fokuserar på nya eller svåra ord (jfr om arbetsminne och hörförståelse, Laakso, 2019), men de kan dock förbättra uttalet av mindre enheter.

Vad gäller rytm har Precis 2 en tipsruta i samband med en uttalsövning. Den anger att "talrytmen i ett främmande språk skiljer sig ofta från modersmålet" (Precis 2, s. 14). I rutan uppmanas inläraren ytterligare att "öva svenskans talrytm genom att klappa händerna eller att stampa takten med foten" (Precis 2, s. 14).

\section{LYSSNA OCH UPPREPA.}

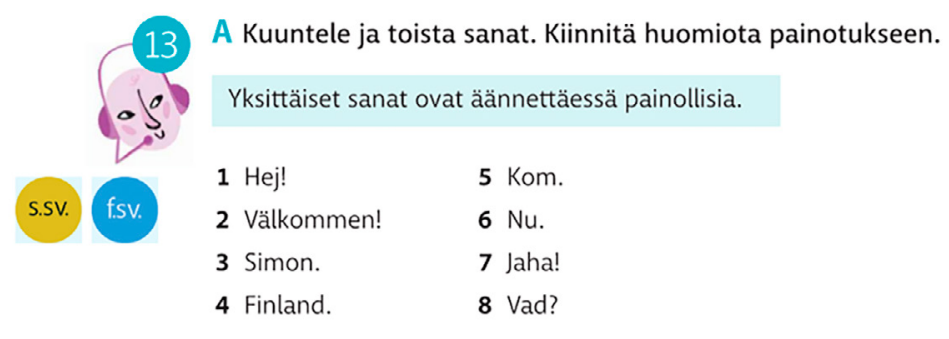

LYSSNA OCH UPPREPA.

B Kuuntele ja toista lauseet.

Lauseissa painotetaan tärkeimpiä tai uutta tietoa sisältäviä sanoja.

1 Jag visste inte att tiden i lumpen går så otroligt fort!

S.sv. f.sv.

2 Jag tycker att det har gått jättesakta! Men tänk om man kunde stoppa klockan och göra om det bästa som hänt.

3 Precis! Då skulle jag välja vår första kvällsfritid!

4 Vad? Varför inte ta den här stunden? Bara två dagar kvar, sen är vi fria!

Painollisia ovat usein substantiivit, adjektiivit, pääverbit, lukusanat ja monet adverbit, verbipartikkelit, nimet ja huudahdukset.

Bild 2. Satsbetoningsövning i Precis 4, s. 83. (sv. 'Lyssna och upprepa orden. Fäst uppmärksamhet vid betoningen. - Enstaka ord betonas vid uttalet. - Lyssna och upprepa meningarna. - I satser betonas de ord som är viktigast eller innebär ny information. - De betonade orden är oftast substantiv, adjektiv, huvudverb, räkneord och flera adverb, verbpartiklar, namn och utrop'.) 


\subsection{Segment-, ord-och satsniva frain begriplighetsperspektiv}

\subsubsection{Segmentnivå}

Begriplighetsperspektivet tas inte upp på segmentnivån i läroboksserierna. Det framkommer inte om vissa segment anses viktigare att behärska än andra: detta kan inte noteras genom anvisningarna eller undervisningsordningen. Upprepningsfrekvensen i Fokus berättar om att uttalet av fonemet /u/ (grafemet $\langle 0\rangle$ ) är väldigt viktigt $-\operatorname{det}$ tas mycket ofta upp. Ett avvikande uttal av fonemet /u/ har dock inte noterats ha betydelse för begripligheten (Heinonen, 2018). Anvisningarna i Precis gäller oftast skillnaden mellan den ortografiska formen och uttalet eller skillnaden i uttalet av segment mellan finska och svenska eller mellan finlandssvenska och sverigesvenska.

De segment som har visat sig förorsaka begriplighetssvårigheter i finskspråkiga talares svenska är ett avvikande uttal av tje-ljudet och klusilerna. Tje-ljudet tas upp i båda serierna och uttalsregler anges en gång (Bild 3, Exempel 2). Klusilerna övas mindre (Tabell 1). I Precis påpekas det att "det är viktigt att kunna hålla isär uttalen av tonande och tonlösa konsonanter" (Precis 2, s. 130). Det anges dock inga förslag på vilket sätt klusilerna kan hållas isär. Varken begreppen aspiration eller stämton nämns i läroboksserierna. Att aspirationen förbises kan föranledas av det eventuella inlärningsmålet: aspirationen gäller inte finlandssvenska där klusilparen skiljs åt snarare genom stämtonen. Om målet är sverigesvenska vore det relevant att nämna aspirationen. De tonande klusilerna $/ \mathrm{b} / \mathrm{och}$ /d/ samt de tonlösa klusilerna /p/och / $\mathrm{t} /$ beaktas inte alls i Fokus. Klusilerna /g/ och /k/ övas men inte med avseende på kontrasten tonlös/tonande utan i samband med olika realisationer av $\langle\mathrm{k}\rangle$ och $\langle\mathrm{g}\rangle$.
Tidigare studier visar att uttalet av sje-ljudet och de sverigesvenska vokalerna [a:], [e:], [o:], [u:] och [y:] också är problematiska att producera för finskspråkiga talare, men segmentens betydelse för kommunikationen har inte påvisats i empiriska undersökningar (Bannert, 1984; Heinonen, 2018; Kuronen, 2016; se också Kautonen m.f., 2016). Sje-ljudet beaktas i läroböckerna: det övas ofta och det ges också uttalsanvisningar om ljudets olika ortografiska motsvarigheter (Exempel 2). Vokalerna [a:], [e:], [o:] och [y:] framhävs i övningarna dock i en mindre grad eller inte alls (Tabell 1). Den mindre rollen kan bero på att deras uttal inte skiljer sig stort mellan finska och finlandssvenska och skillnaden i kvaliteten gäller mer sverigesvenskt uttal. Uttalet av fonemet /u/, / $\mathrm{t} /$ och /y/ kunde dock beaktas noggrannare för att kunna skilja mellan uttalen; En finskspråkig inlärare behöver skapa en ny ljudkategori (finlandssvenskt / t $\mathrm{t} /$ respektive sverigesvenskt/y/) för att skilja mellan dessa tre fonem.

$<$ Exempel 2>

"Käännetään [k], kun sitä seuraavat vokaalit a, a, o tai u. Muulloin se ääntyy suomenruotsissa [t]] ja ruotsinruotsissa [c]. - -

Kirjainyhdistelmät $k j$ ja tj äännetään suomenruotsissa [t]] ja ruotsinruotsissa [c]. - -

Kirjainyhdistelmät -tion ja -sion äännetään subuäänteenä [ك̧̧u:n]. Suomenruotsissa -tion-pääte voidaan ääntää myös [t]u:n]. - -

Sk äännetään [sk], kun sitä seuraavat vokaalit a, $a$, o tai u. Muulloin se äännetä̈n subuäänteenä [J].

Kirjainyhdistelmät sj ja stj äännetään subuäänteenä [J]. - - "3 (Fokus 1, s. 9) 


\section{LYSSNA OCH UPPREPA.}

9 A Kuuntele ja toista sanat.

Kiinnitä huomiota tummennettuihin kirjaimiin.

k lausutaan sanan alussa [k] ennen vokaaleja a, å, o ja u
1 Karlstad
2 kontakt
3 kusinerna

k lausutaan sanan alussa ruotsinruotsissa [6] ennen vokaaleja e, i, y, ä ja ö

fSv. k lausutaan sanan alussa suomenruotsissa [t]] ennen vokaaleja e, i, y, ä ja ö
4 kärlek
5 känslor
6 kyssa

\section{Poikkeuksia}

k lausutaan sanan alussa [k]
7 keps
8 kille
9 kö
10 kör

kj ja tj lausutaan sanan alussa ruotsinruotsissa [ç]

kj ja tj lausutaan sanan alussa suomenruotsissa [t $\mathrm{t}$ ]

$11 \mathrm{kjol}$

12 tjej

Bild 3. Uttalsövningar av tje-ljudet i Precis 3, s. 89. (sv. 'Lyssna och upprepa orden. Fäst uppmärksamhet vid bokstäver med fet stil. k uttalas ordinitialt som [k] före vokalerna a, å, o och u. - - k uttalas ordinitialt [6] före vokalerna e, i, y, ä och ö i sverigesvenska. k uttalas ordinitialt [t] före vokalerna e, i, y, ä och ö i finlandssvenska. - Undantag. k uttalas ordinitialt [k] - kj och tj uttalas ordinitialt [6] i sverigesvenska. kj och tj uttalas ordinitialt [t] i finlandssvenska.')

(sv. 'K uttalas som [k], då den följs av vokalerna $a, a, o$ eller $u$. I andra fall uttalas den [t]] ifinlandssvenska och [c] i sverigesvenska. - Bokstavskombinationerna kj och tj uttalas [t]] ifinlandssvenska och [c] i sverigesvenska. - - Bokstavskombinationerna -tion och -sion

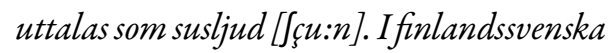
kan-tion-ändelsen uttalas också [t]u:n]. - -

Sk uttalas [sk], då den följs av vokalerna a,

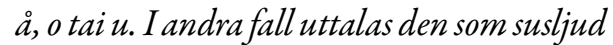
[J]. Bokstavskombinationerna sjoch stj uttalas som susljud [J]. - -')

3 Om fonetiska tecken anger Fokus följande förklaringar: []] sus-s, [t] finlandssvenskans $t+$ sus $s$, [ç] ljud som motsvarar det föregående i sverigesvenska. (Fokus 1, s. 10)

\subsubsection{Ordnivå}

Ordprosodiska drag är viktiga för begripligheten, vilket inte tas upp i läroböckerna. Kvantiteten beaktas i förordet i Fokus 1: det anges att vokalen är lång då konsonanten är kort och den är kort om konsonanten är lång. Finska och svenska skiljer sig i att kvantiteten syns i skrift i finska på ett annat sätt än i svenska: En bokstav motsvarar ett kort ljud och två efterföljande bokstäver utformar ett långt ljud (t.ex. 'sata' (sv. 'hundra'), 'saattaa' (sv. 'kunna' eller 'följa')). Ett bokstavsenligt uttal av svenska kan leda till för korta kvantitetsrealiseringar hos finskspråkiga talare: t.ex. 'val' och 'vall' kan låta lika (se även Bassetti \& Atkinson, 2015), vilket kan påverka begripligheten. I en läroboksorienterad språkundervisning är den skriftliga formen ofta närvarande. Detta ökar behovet av att öka medvetenheten hos 
inlärarna för att de ska kunna tala och läsa målspråket med det målspråkiga systemet (Thorén, 2008, s. 19).

Ordbetoningens plats, som båda serierna tar upp, är viktig från begriplighetsperspektivet: om en fonetiskt obetonad stavelse uppfattas som betonad kan det leda till att lyssnaren inte känner igen ordet (Field 2005; se även Abelin \& Thorén, 2015). Vid sidan av att ange var betoningen är behöver inlärare också kunskap om vad betoning är, dvs. hur betoningen realiseras. Även om finska och svenska skiljer sig från varandra på ordnivån har finskspråkiga talare inte noterats ha större uttalsproblem med kvantitet och ordbetoning (Kautonen 2019; Heinonen, 2018; jfr Bannert, 1984).

\subsubsection{Satsnivå}

Såsom om ordprosodin anger serierna inga anvisningar om realisering av satsprosodin. Som nämnts har båda serierna övningar med fraser och satser och i dessa upprepas oftast ord som förekommer i ordlistan i den föregående övningen. I bästa fall övar satsövningarna såväl uttalet av segment och ordprosodi som satsprosodi, men risken är att inläraren fokuserar på det nya ordet eller ljudet och betonar det fastän ordet är i en obetonad position i satsövningen (se Bild 2, Exempel 1). Detta kan försämra tillägnandet av satsbetoningen (Jones, 1997) och försämra begripligheten (Hahn, 2004).

Prosodiska drag har upptäckts viktiga för begripligheten av svenska och därför betraktas de som det viktigaste inlärningsmålet (Kjellin 2002; Thorén 2008). Att fästa mer uppmärksamhet speciellt vid satsprosodin är angeläget för finskspråkiga svenskinlärare. Finskspråkiga inlärares satsuttal av svenska präglas av att det saknar en tydlig betoning och låter monotont eller att det låter hackigt med för många betoningar (Hildén, 2000; Kautonen, 2019). Den typen av uttal har upplevts av L1-lyssnare som mindre inföddlikt (Kuronen \& Tergujeff, 2017) och mindre begripligt (Heinonen, 2018, 2019) ${ }^{4}$ än uttal med en tydlig satsbetoning. Därför vore det bra med mer fokus och systematiska övningar på satsrytm och satsbetoning.

\subsection{Sättet att presentera uttalet}

Strukturen av segmentövningarna är likartad i läroboksserierna. Övningarna består av en ordlista i vilken vissa bokstäver har skrivits med fet stil. I instruktionerna uppmanas inläraren att lyssna på och upprepa orden. Sättet att presentera och behandla uttalet av segment skiljer sig dock mellan serierna.

Uttalsövningarna i Fokus kan betraktas som implicita. Serien verkar lita på det intuitivt-imitatoriska sättet (se Celce-Murcia m.fl., 2010, s. 2) och effekten av upprepning. Förutom förordet i Fokus 1 ges det inga explicita regler eller anvisningar om uttalet. Det används inte heller fonetiska tecken (jfr Lintunen, 2004) eller andra sätt som skulle göra inläraren medveten om uttalet. Fonetiska tecken förekommer dock i förordet och sporadiskt i samband med ordlistor för ett nytt kapitel men dessa används inte i uttalsövningarna.

Största delen av segmentövningarna i Precis kan betraktas som mer analytiska. Segmenten presenteras systematiskt ett par segment åt gången. I samband med övningarna ges eventuella uttalsregler med fonetiska tecken (se t.ex. Bild 3). Skillnader mellan finska och svenska och mellan finlandssvenska och sverigesvenska varieteterna påpekas explicit. Det kan tolkas som Precis litar på effekten av att medvetandegöra, och orden i övningen demonstrerar regeln eller anvisningen $\mathrm{i}$ praktiken. Skillnaden i approacherna mellan serierna speglas i antalet ord i övningarna: Fokus har fler ord per övning än Precis och

\footnotetext{
${ }^{4}$ Det är viktigt att beakta att dessa undersökningar har publicerats efter läroböckerna i analysen.
} 
således blir det också fler upprepningar per segment och ord under kursernas gång. Precis presenterar också några uttalsinlärningstips $\mathrm{i}$ några tipsrutor, där inläraren uppmanas t.ex. att "fästa uppmärksamhet vid enskilda bokstäver som uttalas på ett annat sätt än i finska och vid betoningen i orden" (Precis 1, s. 16).

Övningarna i ord- och satsuttal kan betraktas som implicita i båda läroboksserierna. Endast ordbetoningens plats nämns explicit (Bild 2) och Fokus 1 ger en förenklad regel av komplementär längd i förordet. I Precis nämns rytm och satsprosodi explicit två gånger: i en tipsruta och i en övning. Övningen fäster uppmärksamhet vid den del som är betonad i en sats och på så sätt gör inläraren medveten om satsbetonade ord. Inläraren har lättare att höra satsbetoningen då hen på förhand vet vad som kommer att betonas i satsen. Annars ges det inga anvisningar eller regler för realiseringen av prosodin och hur den skiljer sig mellan finska och svenska. Om övningarna behandlas som sådana i undervisningen är tillägnandet av ord- och satsprosodin beroende på inlärarens förmåga att intuitivt tillägna sig rytmen, dvs. växlingen i durationerna, intonationen och intensiteten. Det explicita sättet har dock upptäckts effektivare i prosodiinlärningen, speciellt då det är just prosodiska drag som sannolikt transfereras från förstaspråket till målspråket om inläraren inte får några anvisningar (se kapitel 2).

\subsection{Andra anmärkningar om begriplighet och uttalets roll}

I båda läroboksserierna tycks begreppet begriplighet syfta främst till ordförrådet vilket framgår i anvisningarna. Fokus på ordinlärningen visas i ordvalen: "Ur kommunikationens synpunkt är det viktigt att du blir förstådd fastän du inte kommer ihåg just det rätta ordet. Om du inte minns eller vet ordet, försök beskriva det." (Precis 1, s. 25). Fokus kopplar ihop hörförståelsen och ordförrådet: "Studera ord eftersom hörförståelse baserar sig på behärskningen av lexikon" (Fokus 2, s. 7).

Målet att utöka inlärarnas ordförråd syns också i uttalsövningarna. Några övningar har ord vars uttal verkar mindre relevant att öva med tanke på vardagligt språkbruk (jfr Alanen, 2000), t.ex. 'godissnubbe' (Fokus 1), 'mesost' (Fokus 2), 'geografiskt splittrat' (Fokus 3), 'koncentrationsläger', 'bassänghäng' (Fokus 4), 'välstrukna', (Precis 4), 'morgonmålsbåtar' (Precis 5). Detsamma gäller satserna i uttalsövningarna (se 4.1.3). Det större fokuset på ordinlärningen kan hänga ihop med studentexamen som är det viktigaste provet för gymnasister i slutet av utbildningen. Det har hittills varit skriftligt i Finland, och ordförrådet har haft en stor betydelse i det. Inlärningen av nya ord kanhända effektiviseras med hälp av uttalsövningar genom fonologiskt minne.

För inlärning av muntlig färdighet och kommunikationsförmåga kan uttalsövningarnas placering i läroböckerna kritiseras. Uttalsövningarna står oftast separat från andra muntliga övningar, inte sällan efter en diskussionsövning. För att inläraren ska ha lättare att tillämpa de övade uttalskunskaperna vid tal är det rekommendabelt att uttalsövningar placerades i anslutning till muntliga övningar.

\section{SLUTORD}

Syftet med den här kvalitativa innehållsanalysen var att studera hur uttalet presenteras i två finska gymnasieläroboksserier i svenska som andra språk. Analysen visar att utgångspunkten i uttalsövningar är uttalet av segment och ord. Uttalet av segment presenteras i varierande omfattning (se Tabell 1), men segment som ur begriplighetsperspektivet har upptäckts viktiga, dvs. klusiler och tje-ljudet (Bannert, 1984; Heinonen 2018), får inte den största uppmärksamheten. Fokus tar oftast upp 
fonemet / $\mathrm{u} /$ vars uttal inte har ansetts vara viktigt för begripligheten (Heinonen, 2018). Med tanke på ett begripligt uttal är prosodi, speciellt rytm och betoningar, ett av de mer centrala inlärningsmålen (Bannert, 1984; Heinonen, 2018; 2019) men anvisningar om produktionen av prosodiska drag presenteras inte så omfattande (jfr Salenius, 2011; Tergujeff, 2013). Det som tas upp är ordbetoningens placering. Satsbetoning behandlas i en specificerad satsövning i Precis 4. Att känna till betoningens placering är viktigt, men lika viktigt - eller till och med viktigare - är att också känna till vad betoningen innebär (Derwing m.fl., 2013; Derwing m.fl., 1998; Ramírez Verdugo, 2006). Det finns alltså potential att utveckla uttalsövningar till mer fungerande och effektiva.

Det som presenteras av uttalet i läroböckerna motsvarar alltså inte helt de drag som i tidigare undersökningar har upptäckts betydel-

\section{LITTERATUR}

Abelin, Å., \& Thorén, B. (2015). The relative perceptual weight of two Swedish prosodic contrasts. The international symposium on monolingual and bilingual speech 2015, 1-7.

Alanen, K. (2000). Ruotsin kielen lukion oppikirjat kulttuurienvälisen viestinnän näkökulmasta. I: P. Kalaja \& L. Nieminen (red.), Kielikoulussa - kieli koulussa. AFinLAn vuosikirja 58, (s. 187-204). Tillgänglig 23.8.2018 på adressen https://journal.fi/afinlavk/article/view/59840.

Bannert R. (1984). Problems in learning Swedish pronunciation and in understanding foreign accent. Folia Linguistica, 18, 193-222.

Bassetti, B., \& Atkinson, N. (2015). Effects of orthographic forms on pronunciation in experienced instructed second language learners. Applied Psycholinguistics, 36, 67-91.

Bruce, G. (2010). Var fonetiska geografi. Lund: Studentlitteratur. sefulla för kommunikationen i finskspråkiga talares uttal av svenska (t.ex. Bannert, 1984). Utan tilläggsmaterial eller lärares insats kan det bli oklart för inläraren hur prosodiska drag produceras i svenska och vilka uttalsdrag som är viktiga att behärska för att göra sig förstådd (jfr Salo, 2006). I linje med Vaakanainen \& Mäkilä (2018) önskar jag att språkvetenskapliga studier utnyttjas mer i skapandet av läromaterial. Detta sammanfaller också i hur uttalet presenteras i läroboksserierna. Prosodi är ett inlärningsmål vars inlärningsprocess främjas genom explicit undervisning (Derwing m.fl, 1998). För att gymnasister ska kunna nå målet av ett helt begripligt uttal och målet av kunnigheten att tillämpa flera uttalsregler (GLGY, 2015: 251) - är det angeläget att ge regler och anvisningar. Att göra inlärare medvetna om de mest betydelsefulla uttalsdragen för kommunikationen är ett viktigt steg mot ett lättbegripligt uttal.

Celce-Murcia, M., Brinton, D. M., \& Goodwin, J. M. (2010). Teaching pronunciation hardback with audio CDs (2): A course book and reference guide. Cambridge University Press.

Crowther, D., Trofimovich, P., Saito, K., \& Isaacs, T. (2015). Second language comprehensibility revisited: Investigating the effects of learner background. TESOL 2uarterly, 49, 814-837.

Derwing, T. M., Diepenbroek, L. G., \& Foote, J. A. (2013). How well do general-skills ESL textbooks address pronunciation? TESL Canada Journal, 30, 22-44.

Derwing, T. M., Munro, M. J., \& Wiebe, G. (1998). Evidence in favor of a broad framework for pronunciation instruction. Language Learning, 48, 393-410.

Fant, G. \& Kruckenberg, A. (1994). Notes on stress and word accent in Swedish. STL-QPSR 2-3, 125-144.

Field J. (2005). Intelligibility and the listener: The role of lexical stress. TESOL 2uarterly, 39, 399-423. 
GLGY.(2003). Grunderna för gymnasiets läroplan 2003. Tillgänglig 29.11.2016 på adressen http://www.oph.fi/lagar_och_anvisningar/ laroplans-_och_examensgrunder/gymnasiet.

GLGY.(2015). Grunderna for gymnasiets läroplan 2015. Tillgänglig 29.11.2016 på adressen http://www.oph.fi/lagar_och_anvisningar/ laroplans-_och_examensgrunder/gymnasiet.

Hahn, L. D. (2004). Primary stress and intelligibility: Research to motivate the teaching of suprasegmentals. TESOL Quarterly, $38,201-223$.

Heinonen, H. (2019). Durationsförhållandena i finskspråkiga gymnasisters uttal av L2-svenska: hur relaterar de till begripligheten? I: M. Bianchi, D. Håkansson, B. Melander, L. Pfister, M. Westman \& C. Östman (red.), Svenskans beskrivning 36. Förhandlingar vid trettiosjätte sammankomsten. Uppsala 25-27 oktober 2017, (s. 95-106). Uppsala: Institutionen för nordiska språk.

Heinonen, H. (2018). Uttalsfärdigheter och begriplighet i finskspråkiga gymnasisters L2svenska. I: B. Silén, A. Huhtala, H. LehtiEklund, J. Stenberg-Sirén \& V. Syrjälä (red.), Svenskan i Finland 17. Föredrag vid den sjuttonde sammankomsten for beskrivningen av svenskan i Finland. Nordica Helsingiensia, 53, (s. 32-45). Helsingfors: Helsingfors universitet.

Hildén R. (2000). Att tala bra, bättre och bäst - Suomenkielisten abiturienttien ruotsin kielen suullinen taito testisuoritusten valossa. Helsingfors: Helsingfors universitet.

Huhtamäki, M. \& Zetterholm, E. (2017). Uttalets plats i undervisningen av svenska som andraspråk. I: M. Kuronen, P. Lintunen \& T. Nieminen (red.), Insights into second language speech, (s. 45-60). AFinLA-e n:o 10. DOI: https://doi.org/10.30660/afinla.73123

Jones, R. H. (1997). Beyond "listen and repeat": Pronunciation teaching materials and theories of second language acquisition. System, 25, 103-112.

Kautonen, M. (2019). Finskspråkiga inlärares uttal av finlandssvenska i fritt tal på olika färdighetsnivåer. JYU dissertations, 90. Jyväskylä: Jyväskylä universitet.

Kautonen, M., Kuronen, M. \& Ullakonoja, R. (2016). Studier i uttalsinlärning i finska, svenska och engelska: Litteraturöversikt. Puhe ja kieli, 36, 197-220.
Kjellin, O. (2002). Uttalet, språket och hjärnan: teori och metodik för språkundervisningen. Uppsala: Hallgren \& Fallgren.

Kulmala, M. (2013). Muntliga övningar i två läroboksserier. Kandidatavhandling. Jyväskylä: Jyväskylä universitet.

Kuronen, M. 2016. Avancerade finskspråkiga inlärares uttal av segment i sverigesvenska. Pube ja kieli, 36, 175-196.

Kuronen, M. \& Tergujeff, E. (2017). L1 listeners' perception of L2 pronunciation - Effect of prosody on accentedness ratings in Swedish. I: M. Kuronen, P. Lintunen \& T. Nieminen (red.), Insights into second language speech, (s. 214-233). AFinLA-e n:o 10. DOI: https:// doi.org/10.30660/afinla.73138

Kuronen, M. \& Zetterholm, E. (2017). Olika fonetiska drags relativa betydelse för upplevd inföddlikhet i svenska. Nordand, 2, 134-156.

Laakso, S. (2019). Rajallinen työmuisti S2oppijoiden puheenymmärtämisvaikeuksien selittäjänä. Puhe ja kieli, 38, 181-202.

Levis, J. (2005). Changing context and shifting paradigms in pronunciation teaching. Tesol Quarterly, 39, 369-377.

Lintunen, P. (2004). Pronunciation and Phonemic Transcription: A study of advanced Finnish learners of English. Åbo: Åbo universitet.

Lintunen P. (2014). Ääntämisen oppiminen ja opettaminen. I Pietilä P. \& P. Lintunen (red.): Kuinka kieltä opitaan: opas vieraan kielen opettajalle ja opiskelijalle, (s. 165-187). Helsinki: Gaudeamus.

Luukka, M. R., Pöyhönen, S., Huhta, A., Taalas, P., Tarnanen, M., \& Keränen, A. (2008). Maailma munttuu-mitä tekee koulu? Äidinkielen ja vieraiden kielten tekstikäytänteet koulussa ja vapaa-ajalla. Jyväskylä: Jyväskylä universitet, Centralen för tillämpad språkforskning.

Lynch, T. (1998). Theoretical perspectives on listening. Annual review of applied linguistics, 18, 3-19.

Munro, M. J., \& Derwing, T. M. (2006). The functional load principle in ESL pronunciation instruction: An exploratory study. System, 34, 520-531.

Saito, K., Trofimovich, P. \& Isaacs, T. (2016). Second language speech production: Investigating linguistic correlates of comprehensibility and accentedness for learners at different ability levels. Applied Psycholinguistics, 37, 217-240. 
Salenius, A. (2011). Taking it a tad further: comparing English and Swedish course materials in terms of presenting prosody and accent variation. Magisteravhandling. Jyväskylä: Jyväskylä universitet.

Salo, O. P. (2006). Opetussuunnitelma muuttuu, muuttuuko oppikirja?: Huomioita 7. luokan vieraiden kielten oppikirjojen kielikäsityksistä. I: P. Pietilä, P. Lintunen \& H.-M. Järvinen (red.) Kielenoppija tänään - Language Learners of Today, (s. 237-254). AFinLAn vuosikirja 64.

Ramírez Verdugo, D. (2006). A study of intonation awareness and learning in non-native speakers of English. Language Awareness, 15, 141-159.

Tergujeff, E. (2013). English pronunciation teaching in Finland. Jyväskylä studies in humanities, 207. Jyväskylä: Jyväskylä universitet

Thorén B. (2008). The priority of temporal aspects in L2-Swedish prosody. Studies in perception and production. Stockholm: Stockholms universitet.

Vaakanainen V. \& Mäkilä M. (2018). Meningsstruktur i två läroboksserier för svenskundervisning på högstadienivå. I: B. Silén, A. Huhtala, H. Lehti-Eklund, J. StenbergSirén \& V. Syrjälä (red.), Svenskan i Finland 17. Föredrag vid den sjuttonde sammankomsten för beskrivningen av svenskan i Finland, (s. 168182). Nordica Helsingiensia 53. Helsingfors: Helsingfors universitet.

Vihanta V. (1990). Suomi vieraana kielenä foneettiselta kannalta. I: J. Tommola (red.) Foreign language comprehension and production, (s. 199-225). AFinLA Yearbook 1990. Åbo: Suomen soveltavan kielitieteen yhdistys.

YTL. (2016). Ylioppilastutkintolautakunta. Ylioppilastutkintoon osallistujat kokeittain. Tillgänglig 19.5.2016 på adressen https:// www.ylioppilastutkinto.fi/images/sivuston_ tiedostot/stat/FB2016KT2001.pdf.

Wrembel M. (2010). L2-accented speech in L3 production. International Journal of Multilingualism, 7(1), 75-90.

\section{LÄROBÖCKERNA I ANALYSEN}

Appel M., Fagerholm, H., Johansson K., Määttä, O., Pesola S., Silén M., Steenbeck, A., Tiala T. (2017). Precis 1 (en digital parallelversion). Helsinki: Sanoma Pro Oy.

Appel M., Johansson K., Määttä, O., Pesola S., Silén M., Steenbeck, A. \& Tiala T. (2016). Precis 2 (en digital parallelversion). Helsinki: Sanoma Pro Oy.

Appel M., Bulut S., Johansson K., Jämsén S., Jääskeläinen M., Määttä, O., Silén M., \& Tiala T. (2015). Precis 3 (en digital parallelversion). Helsinki: Sanoma Pro Oy.

Appel M., Bulut S., Johansson K., Jääskeläinen M., Määttä, O., Salonen T., \& Tiala T. (2017). Precis 4 (en digital parallelversion). Helsinki: Sanoma Pro Oy.

Appel M., Bulut S., Johansson K., Jääskeläinen M., Määttä, O. \& Tiala T. (2016). Precis 5 (en digital parallelversion). Helsinki: Sanoma Pro Oy.

Blom, A., Kaunisto S., Paasonen M. \& Salonen A. (2015). Fokus 1. Helsingfors: Otava.

Blom, A., Kaunisto S., Paasonen M., Pajunen M. \& Salonen A. (2016). Fokus 2. Helsingfors: Otava.

Blom, A., Kaunisto S., Paasonen M., Pajunen M. \& Salonen A. (2016). Fokus 3. Helsingfors: Otava.

Blom, A., Kaunisto S., Paasonen M. \& Salonen A. (2017). Fokus 4. Helsingfors: Otava.

Blom, A., Friis, M., Kaunisto S., Paasonen M. \& Salonen A. (2017). Fokus 5. Helsingfors: Otava. 


\section{ÄÄNTÄMISEN KÄSITTELY RUOTSIN KIELEN OPPIKIRJOISSA YMMÄRRETTÄVYYDEN NÄKÖKULMASTA}

Henna Heinonen, Jyväskylän yliopisto

Tässä artikkelissa tarkastelen, kuinka ääntämistä käsitellään lukion keskipitkän oppimäärän ruotsin oppikirjoissa $(n=10)$. Selvitän, mitä ääntämisen piirteitä oppikirjoissa esitellään, ja analysoin piirteiden ja ymmärrettävyyden välistä suhdetta. Tutkimusmetodina käytän laadullista sisällönanalyysia.

Prosodisten piirteiden onnistuminen helpottaa kuulijaa ymmärtämään puhujaa. Ruotsissa erityisesti lauserytmin on huomattu olevan yhteydessä puheen ymmärrettävyyteen. Tämä oppikirja-analyysi kuitenkin osoitti, että oppikirjoissa huomio kiinnitetään usein yksittäisiin äänteisiin ja sanoihin. Kokonaisten lauseiden ääntämistä harjoitetaan myös, mutta prosodisten piirteiden tuottamiseen liittyviä sääntöjä tai ohjeita on todella vähän. Täsmällisten ohjeiden ja tietoisuuden herättämisen on aiemmissa tutkimuksissa huomattu olevan tehokkaita, jopa välttämättömiä, prosodisten piirteiden oppimisessa.

Keskipitkän ruotsin oppimäärän tavoitteina on helposti ymmärrettävä ääntäminen sekä useiden ääntämissääntöjen soveltaminen. Sääntöjen ja ohjeiden puutteellisuus oppikirjoissa kasvattaa opettajan roolia tavoitteiden saavuttamisessa. Ymmärrettävään ääntämiseen tähtäävässä opetuksessa juuri prosodisten piirteiden esitteleminen ja harjoittaminen tulisi olla avainasemassa.

Avainsanat: oppikirja-analyysi, ymmärrettävyys, ääntäminen

\section{PRONUNCIATION IN TEXTBOOKS IN SWEDISH AS L2 FROM A COMPREHENSIBILITY PERSPECTIVE}

Henna Heinonen, Department of Language and Communication Studies, University of Jyväskylä

This study focuses on how pronunciation is presented in Finnish textbooks in Swedish as L2 $(n=10)$. The textbooks are aimed for upper secondary school students at intermediate level. The pronunciation features presented in the textbooks are analyzed from the perspective of comprehensibility.

It is well known that prosodic features have a great impact on comprehensibility of speech. Concerning Swedish, sentence rhythm is one of the most important features. Yet, this analysis showed that individual speech sounds and single words are paid a lot of attention to. Also, whole sentences are practised in some exercises, but there is a lack of rules or instructions on how to produce prosodic features. Explicit instructions and awareness raising have been suggested to be effective, or even necessary, in learning prosody. 
The learning goals at this proficiency level is to gain comprehensible pronunciation and to be able to apply several pronunciations rules. The absence of rules and instructions in textbooks makes the teacher's role more important in reaching the goals. Presenting and practising prosodic features should be in a key position in language teaching that aims for easily comprehensible pronunciation.

Keywords: comprehensibility, pronunciation, textbook analysis 